\title{
194. 外耳道造設術の工夫
}

——字鋼状胁軟骨フレームと有茎骨膜弁に上る前壁形成法——

○関 谷透（山口大）

著しい小耳症在伴小ない先天性外耳道開顉症に対して 比赖的安易に手術的開空と外耳道造設が行われる傾向が ある、そして術後まもなく再䧆窄〜関鎖することが多 い. 私は one stage に行方外耳道造設術を工大・施行 し好結果索得たので術山手技の留意事項を含めて報告し た. 基本的には新設外耳道の前壁を，1）L宇鋼状肋軟 骨フレーム上，2）䚟状部有荎骨膜上で作る。3）後壁

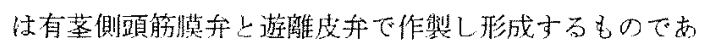

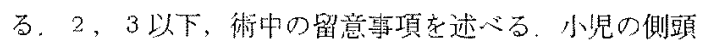
骨解剖の特異性に留意しとくに術捘顔麻のおこらぬ上う 注意する。

耳後切開，切開の梁さ蛙骨膜上にとどめ，このレぶル

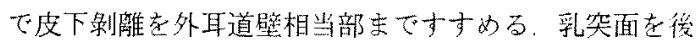

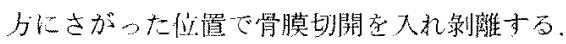

一応豉室骨の有無を確加る。この際, 茎乳乫孔, 顔 面神経管り位置異常に注意寸各、剥離した乳㔖前面の骨 膜とその前部の軟部組織上の閒在到離しポケット状空隙
を作る。

L字鋼状胁軟骨フレームの作製. 採取した自家助軟骨 の彫骨に先立ち，厚紙（1.5mm 厚さ）で插入形成に適合 した奏物紙型を作っておく之良い，小孔をつける(活着 性の良い招軟骨にさらに良く着き，加良い固定を得る ために〉。このフレームは促来法のものに比して薄いが 耐压性, 空間性に富卆。フレーム雨入, 有茎骨膜被覆. その上に耳介窩加有荎皮弁在内に入被覆, 維合固定す る.

露出した乳突部骨面一後壁相当部一上小鼓室（あ九 ば）は有菱の側頭筋筋膜升で被い，さらに耳介窝皮膚欠 損部を装醅した皮膚（遊離）の内半部圭用いて被覆（縫 合固定).この形成外耳道腔法短冊状トレックス・ガー ゼ十文字雨入（法）で均一に圧迫し，かつ湥出物排出を は名る。耳徭部切開創注 2 層縫合（埋没法）により 1 次 的に閉鎖する，術後処置は鼓室成形術に準じて行らもの である。

\section{5. 新しい鼓膜麻酔法 一イオン浸透圧鼓膜麻酔法一}

\section{○長谷川 誠・奥野 秀次・小林 秀紀・野口 明彦・斉藤 洋三（東医菌大）}

鼓膜は耳鼻咽喉科領域で最も麻酔のしにくい部分であ

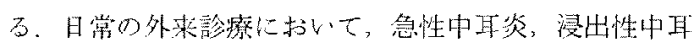

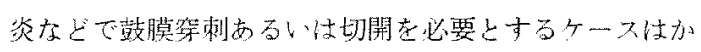
なり多い，無麻酔で鼓膜を穿刺，切開する場合，患者は

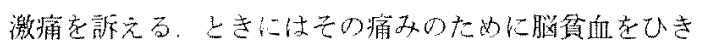
起し、治潦心支障をきたすこともある、特に鼓荧穿刺， 切開を必要与する患者は幼小児に多々，有刘な鼓膜麻睡 法の出現が望まれてきた。

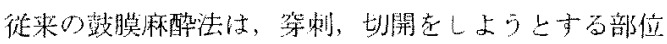
に，塩酸コカインやキシロカイン老浸した小綿花を密着 させ，それにより無痛をえようとしてきた。しかしこの 方法では浣全な無痛をらることは大変むずかしく，特に 小見ではむし万無麻酔方行つた力がやりや寸いとさえ言

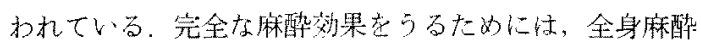
在行うしかなく、すぶての例にこれを行うわけに林いか
ない

今回和机わ机㤬，40症例に対してイオン浸透圧鼓膜麻 酔法を行ったところ，画期的な成果をうることができた ので報告才る。40症例の内訳梳、浸出性中耳炎患者 29 名 (男19名, 4 才〜 78才, 女10名, 4 才 65 才) と邓 = 一儿病患者11名（男2名, 29才 54才, 女9名, 31才 72才)である。麻酔効果恃全症例につききわ力て満足し うるものであった。浸出性中耳㷋群は全例無痛状態で鼓 膜切開およひ鼓膜換谷チューブの挿入を行うことができ た。メニエール病患者の鼓膜は一般に正常鼓獏と考えて よいので,この群はコントロールとして用いた。この場 台の麻酙効果は耳用ゾンデにより鼓膜を刺激し。痛みが まったくなくなることにより判定し全例にこの効果を認 めた，鼓膜麻酔上同側の味覚減退が浸出性中耳炎群で 6 例, メニエール病群で 2 例認められた。 これは鼓索神経 
がブロックされたことを意味する，麻配時の耳の柽度の 不快感を訴えた例が 3 例あった他は，特に著しい副作用
注認めら机方かった。

\section{6. 滲出性中耳炎に対する乳突削開術について}

\section{○調賢哉(日田市)}

私其の臨林に扔いて現在もなお蜼治で恼まされる疾患 O1つに滲出性中耳炎があり，経鼓膜的千ェーブ聥入法

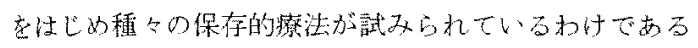

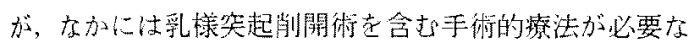
症例坊ある。

症 例：35才男子：渗出性中耳次で䄪6年間，数人の 耳科医に上り保存的に治療索うけなが効果のみなれなか

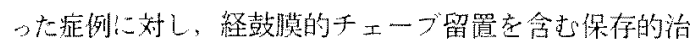

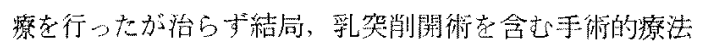
行って治棠せしめた。

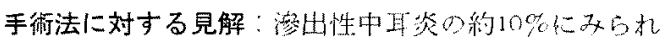
西難治例中，鼓空空内に渗出液貯留を絽り返し，レント

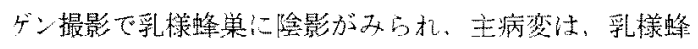

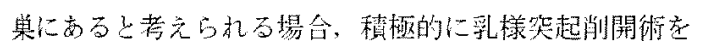
行鴓要がある。

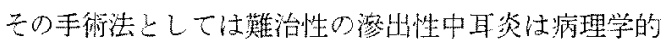

には tubotympanomastoiditis と壳えるけだ，たとえ主 病変が mastoid にあるとしても耳管扩よび鼓空粘膜の

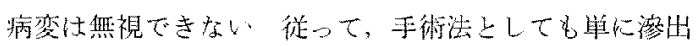
液の depot上しての乳様衉笨茥削開するだけでなく，耳

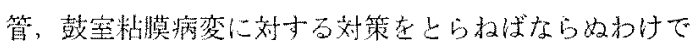
ある，そのため满来上り乳笑削開と経鼓膜的チューブ捔 入法起件用したり (SHEEHY) また, 乳知削開後, depot 起十分搪け、保存的中耳根治手術の型式としたり，facial

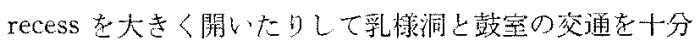
につけたりしている(宫尾，神尾，中野，SHEEHY）。私

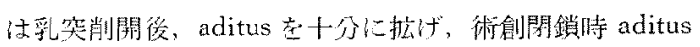

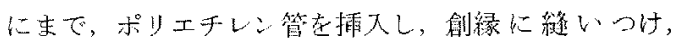

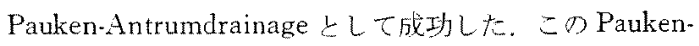

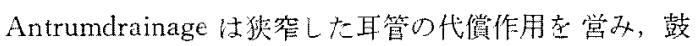
室および耳管粘艊脑変の治療, 機能の正常化䘮促進させ るものと思加れ。

\section{7. 顕微鏡下の中耳疾患の診療}

$$
\text { ○鍮 木 淳 - - (帝京大) }
$$

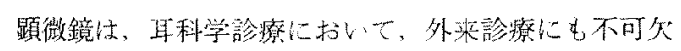

の器械となった。

術前の鼓膜・中耳腔の锥察，李た，上くにいわゆる 「パチ・テスト」施行に注影微鏡が必要しなる。目小

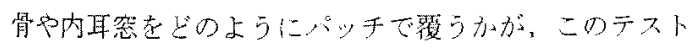
の成否のかなるであるからでる。

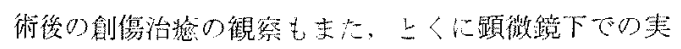

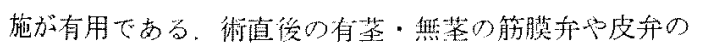
生着や感染の有様仕, 䁰徽鏡下での维察が必須である。

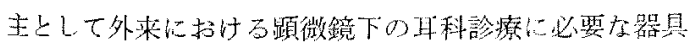
仕,
1)小から超特大尘での黑塗りの耳鏡

2)外耳道を気密にして検鏡するための黑涪り変形ジ 一ダル耳錇

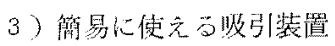

4) 耳用小器椷(鈍斜, 鋭题, 鉜子など) などである。 中耳の手衔に用いる器械区使利なるのは数参いが，自 身の工夫になるむの上しては，

1)大・中・小極小の直型テラみ又（曲型は以前よ )存在(た)

2) 小型可㩭の鋭㗹

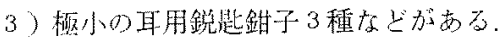

